\title{
CB Research Square \\ Phytochemicals Target Growth Factor Receptors to Control Cancer: An In Silico Study
}

\section{Love Edet Mendie}

B.S. Abdur Rahman Crescent institute of Science and Technology

S Hemalatha ( $\boldsymbol{Q}$ hemalatha.sls@bsauniv.ac.in)

B.S. Abdur Rahman Crescent institute of Science and Technology https://orcid.org/0000-0002-8150-7721

\section{Research Article}

Keywords: GFR, Drug delivery, ADMET, Molecular docking, Cancer

Posted Date: August 10th, 2021

DOI: https://doi.org/10.21203/rs.3.rs-768199/v1

License: (a) (1) This work is licensed under a Creative Commons Attribution 4.0 International License. Read Full License 


\section{Abstract}

Drug delivery in a safe manner is a major challenge in the drug development process. Growth factor receptors (GFRs) are known to have profound roles in the growth and progression of cancerous cells making these receptors a therapeutic target in the effective treatment of cancer. This work focused on exploring bioactive compounds that can target GFRs usingin-silico method. In this study, 50 bioactive compounds from different plant sources were screened as anticancer agent against GFRs using drug likeness parameters of Lipinski's rule of five. The molecular docking was performed between phytochemicals and GFRs. Ligands with acceptable drug likeness and binding energy comparable to the standard drugs were further screened to determine their pharmacokinetic activities. This study showed phytochemicals with the binding energy comparable with the standard drugs (Dovitinb and Geftinib), while ADME, bioactivity score and bioavailability radar analysis gave further insight on these compounds as potent anticancer agents.

\section{Introduction}

Multiple alterations in the gene expression leads to imbalance in cellular proliferation resulting in abnormal growth of cells called cancer. Over the years, cancer has been a persistent public health problem recorded as the major cause of death in both developed and developing countries worldwide [1, 2]. Research shows that an estimated number of 23.6 million new cases of cancer are likely to be recorded per year by 2030 [3]. Cancerous cells have special ability of survival, immortality, self-sufficiency of growth signals, unlimited replication, gene instability, evading programmed cell death, continuous angiogenesis and diverse mutations [4]. Growth factor receptors (GFRs) are proteins thathave profound roles in tumor growth of cell, metastasis, angiogenesis, cell survival,cell death, cell migration, differentiation,organogenesis, neovascularization, and chemoresistance, activated by binding with their ligands (growth factors) [5-7]. These receptors highly involved in cancer progression includes epidermal growth factor receptors (EGFRs), insulin-like growth factor receptor (IGFR), vascular endothelial growth factor receptor (VEGFR), transforming growth factor-beta receptor (TGF- $\beta R$ ), fibroblast growth factor receptor (FGFR) and platelet-derived growth factor receptor (PDGFR). In some cancer, these receptors are often overexpressed leading to uncontrolled proliferation and differentiation, ${ }^{[8]}$ their amplification activates both inherent and acquired resistance to cancer treatments. Overexpression of HER-2 gene were found in breast, bladder, lung and glial carcinomas, HER-3 gene in aggressive metastatic breast, ovarian, lung, gastric, invasive urothelial bladder and endometrial carcinomas, VEGFR1-3genes found in large number of tumors like bladder, colon, breast, lung, brain, prostate, gastric, kidney, thyroid and ovarian cancer cells, FGFR-2 gene in gastric, breast, endometrial and lung carcinomas [6, 9]. The role of these receptors in cancer progression has made them a necessary therapeutic target for effective cancer therapy.

Presently, the treatment of cancer involves the use of chemotherapy, radiotherapy, immunotherapy, surgery and anticancer drugs, all of which have been proven to be less effective due to disadvantages of recurrence, drug resistance, effect on non-targeted cell and other various side effects and toxicity that accompanies them [2, 4].

Studies have shown that phytochemicals are powerful anticancer agents, with benefits greater than synthetic compounds, ranging from less toxicity, ease of extraction to large abundance [10]. About $35 \%$ of cancer cases can be addressed by establishing a proper dieting which largely involves the consumption of plant-derived foods such as vegetables, fruits and whole grains that contains carotenoids, flavonoids and phenolics [11-13]. Phytochemicals possesses various mechanisms to shut down or slow down cancer growth and progression by reducing oxidative stress, suppressing proliferation of cells, causing programmed cell death, preventing angiogenic process, as well as cell cycle arrest $[2,11]$. Studies showed that not less than 60 phytochemicals are currently in the pipeline as

Page 2/19 
potential anti-cancer agents [14-16]. Developing anti-cancer drug requires blocking one or more proteins or pathways involved in cancer development. In this present studies, 50 phytochemicals were evaluated against EGFRs (HER-2 and HER-3) VEGFR (VEGFR-2 and VEGFR-3) and FGFR (FGFR-2) to determine potential lead agents for the development of anti-cancer drugs.

\section{Materials And Method}

\section{Selection and preparation of ligands}

50 bioactive compounds from different plant source collated from public database and publishedresearch papers were downloaded fromhttps://pubchem.ncbi.nlm.nih.govin SDF format. Also, two standard drugs Dovitinib and Gefitinibwith Pubmed IDCID_135398510 and CID_123631 respectively, were downloaded in 3D Sdf format for comparism with the phytochemicals. Using the software open babel (http://openbabel.org/wiki/Main_Page), these ligands werechanged to PDB format which makes them suitable for docking analysis. This was followed by setting the torsion requirements for proper binding using Autodock4.2.6 parameters.

\section{Proteins Preparation}

3D structures of human endothelial receptor (HER-1 and HER-2), vascular endothelial growth factor receptor (VEGFR-2 and VEGFR-3) and fibroblast growth receptor (FGFR-2) were downloaded from RCSB protein data bank (http://www.rcsb.org/pdb/home/home.do)with PDB ID 1MFG for HER2, 60P9 for HER3, 3VHE for VEGFR-2, 4BSJ for VEGFR-3 and 2PVF for FGFR-2. Using Autodock 4.2.6, removal of water molecules and addition of polar hydrogen and kollman's charges were done, these proteins were saved in PDBQT format.

\section{Docking Analysis}

After the proteins and ligands preparation, molecular docking was executed using Autodock4.2.6. For binding to take place $\mathrm{x}, \mathrm{y}$ and $\mathrm{z}$ dimensions were set at $60 \mathrm{x} 60 \mathrm{x} 60$ with a resolution of $0.500 \AA$ and grid box centered to obtain favourable docking conformations. The grid file was saved as (.gpf) file and run autogrid. Docking calculation was then carried out using the Lamarckian genetic algorithm with the default at 10 runs. Dock file was saved as dpf and after running autodock, final docked results were obtained in (.dlg) file which showed information such as binding residues, binding energy and inhibition constant. The structures showing interaction between ligands and proteins were viewed using Discovery Studio.

\section{Rule of Five (RO5)}

Lipinski's RO5 is used for evaluation of drug-likeness of a compound, a necessary step in drug discovery which helps to determine if a certain compound is likely to be orally active. In this study, ligands were screened for the RO5 using the Supercomputing facility for bioinformatics and computational biology (http://www.scfbio-iitd.res.in/software/drugdesign/lipinski.jsp) [17, 18]. Bioactive compounds with binding energy comparable to standard drugs were subjected to this analysis.

\section{In silico ADME Analysis}

Pharmokinetics parameters such as Absorption, Distribution, Metabolism and Excretion were evaluated in the ligands using SwissADME (http://www.swissadme.ch/index.php). The essence of this assay is to provide insights that will be useful in drug research and development process.

\section{Bioactivity Score and Bioavailabilty radar}

The bioactivity score of ligands were determined employing online Molinspiration software (http://www.molinspiration.com/). This was done by applying canonical SMILES of ligands obtained fromPubChem. Properties analyzed includes G-protein coupled receptors (GPCR), enzyme inhibitors (EI), kinase inhibitors (KI), nuclear receptors ligands (NRL) and ion channel modulators (ICM). The bioavailbilty radar ligands were determined by using SwissADME (http://www.swissadme.ch/index.php) which instantly shows if a compound is orally bioavailable.

\section{Results And Discussion}




\section{Docking Analysis}

Due to the roles growth factor receptors play in the development and progression of cancer, it is necessary to develop suitable drug candidates that can effectively inhibit growth factors at the sites of receptors with little or no effects. Binding affinity between ligands and receptors is determined by the binding energy, the lower the energy the higher the binding affinity [9]. For this purpose, 50 bioactive compounds were screened against ERRB2/HER2, ERRB3/HER3, VEGFR-2, VEGFR-3 and FGFR-2. Commonly used anticancer drugs (Dovitinib and Gefitinib) that have activities against the target receptors were docked against the proteins and their binding energies used as comparison with the binding energies of the selected. After docking, the binding energy $(\mathrm{kcal} / \mathrm{mol})$, number of hydrogen bond, inhibitory constant $(\mu \mathrm{M} / \mathrm{nM})$ and amino acids involved in hydrogen bonding were noted.

Out of the 50 phytochemicals, 14 have binding energy comparable to the standard drug for HER2 (Table 1, Fig. 1). Dovitinib and Gefitinib have binding energy of-6.03Kcal $/ \mathrm{mol}$ and $-6.59 \mathrm{Kcal} / \mathrm{mol}$ respectively, with amino acid involved in hydrogen bond as LYS1326 and GLN1329 for Dovitinib and LEU1291 for Geftinib

Table1. Interaction of phytochemicals with target protein HER-2

\begin{tabular}{|c|c|c|c|c|}
\hline Phytochemicals & $\begin{array}{l}\text { Binding Energy } \\
\text { (Kcal/mol) }\end{array}$ & $\begin{array}{l}\text { Inhibition } \\
\text { constant }(\mu \mathrm{M})\end{array}$ & $\begin{array}{l}\text { Number of } \\
\text { Hydrogen } \\
\text { bond }\end{array}$ & $\begin{array}{l}\text { Amino Acids involved in hydrogen } \\
\text { bonding }\end{array}$ \\
\hline Andrographolide & -7.19 & 5.32 & 3 & $\begin{array}{l}\text { GLU 1290, LEU 1291, LEU 1354, SER } \\
\text { 1294, LYS 1355, ILE } 1295\end{array}$ \\
\hline Colchicine & -8.07 & 1.21 & 3 & ILE 1295, PHE 1293, LYS 1287 \\
\hline Corydine & -6.63 & 13.83 & 4 & $\begin{array}{l}\text { GLN 1319, SER 1294, PHE 1293, ILE } \\
1295\end{array}$ \\
\hline Crocetin & -7.39 & 3.86 & 2 & ASN 1359, ILE 1295 \\
\hline Curdione & -7.14 & 5.81 & 2 & LEU 1291, GLY 1292 \\
\hline Nimbolide & -7.55 & 2.91 & 2 & LYS 1355, PHE 1293 \\
\hline Oleanolic acid & -7.87 & 1.71 & 1 & PHE 1293 \\
\hline Panaxadiol & -7.08 & 6.45 & 2 & ILE 1293, LEU 1291 \\
\hline Panaxatriol & -6.94 & 8.23 & 1 & PHE 1293 \\
\hline Salvicine & -6.61 & 14.18 & 4 & $\begin{array}{l}\text { LEU 1291, PHE 1357, LYS 1287, PRO } \\
1289\end{array}$ \\
\hline Tetrandrine & -7.06 & 6.67 & 1 & SER 1294 \\
\hline Ursolic acid & -7.32 & 4.34 & 2 & ILE 1295, LEU 1291 \\
\hline Withaferin A & -8.29 & 833.27nM & 2 & THR 1316, SER 1294 \\
\hline Hecogenin & -9.00 & $252.95 \mathrm{nM}$ & 2 & ILE 1295, PRO 1289 \\
\hline $\begin{array}{l}\text { Dovitinib } \\
\text { (Standard drug) }\end{array}$ & -6.03 & 37.91 & 2 & LYS 1326, GLN 1329 \\
\hline $\begin{array}{l}\text { Gefitinib } \\
\text { (Standard drug) }\end{array}$ & -6.59 & 14.83 & 1 & LEU 1291 \\
\hline
\end{tabular}


19 phytochemicals for HER3 as shown in Table 2 and Fig. 2, having Dovitinib and Gefitinib with binding energy of$8.77 \mathrm{Kcal} / \mathrm{mol}$ and $-6.89 \mathrm{Kcal} / \mathrm{mol}$, with amino acid involved in hydrogen bond as LEU771 for Dovitinib and CYS721 and LEU771 for Geftinib.

Table 2. Interaction of phytochemicals with target protein HER-3

\begin{tabular}{|c|c|c|c|c|}
\hline Phytochemicals & $\begin{array}{l}\text { Binding Energy } \\
\text { (Kcal/mol) }\end{array}$ & $\begin{array}{l}\text { Inhibition } \\
\text { constant }(\mu \mathrm{M})\end{array}$ & $\begin{array}{l}\text { Number of } \\
\text { Hydrogen bond }\end{array}$ & $\begin{array}{l}\text { Amino Acids involved in } \\
\text { hydrogen bonding }\end{array}$ \\
\hline Andrographolide & 8.07 & 1.21 & 4 & $\begin{array}{l}\text { LYS 723, LEU 771, GLY 774, } \\
\text { ASP } 833\end{array}$ \\
\hline Bassic acid & -8.14 & 1.08 & 2 & PRO 772, ASN 820 \\
\hline Crocetin & -7.81 & 1.90 & 2 & GLN 769, LYS 853 \\
\hline Curdione & -7.26 & 4.76 & 0 & - \\
\hline Etoposide & -7.51 & 3.12 & 4 & $\begin{array}{l}\text { LEU 771, LYS 723, PHE 701, } \\
\text { ASN } 815\end{array}$ \\
\hline Genkwanin & -7.00 & 7.37 & 3 & LEU 771, LYS 723, ASP 833 \\
\hline Licochalcone A & -7.04 & 6.90 & 2 & LYS 723, VAL 753 \\
\hline Nectandrin B & -7.23 & 4.98 & 2 & ASN 820, PHE 834 \\
\hline Nimbolide & -7.83 & 1.81 & 3 & PHE 701, LYS 723, LYS 853 \\
\hline Oleanolic acid & -9.86 & $59.54 \mathrm{nM}$ & 3 & THR 768, LYS 723, ARG 819 \\
\hline Panaxadiol & -10.04 & 43.39nM & 0 & - \\
\hline Panaxatriol & -8.91 & 296.37nM & 1 & ASP 833 \\
\hline Salvicine & -8.83 & $337.56 \mathrm{nM}$ & 2 & ASP 833, GLN 769 \\
\hline Tetrandine & -7.34 & 4.18 & 1 & ARG 781 \\
\hline Theaflavin & -7.90 & 1.62 & 5 & $\begin{array}{l}\text { LEU 771, GLN 769, CYS 721, } \\
\text { THR 768, ASP } 833\end{array}$ \\
\hline Tylophorine & -7.55 & 2.94 & 2 & CYS 721, LYS 723 \\
\hline Ursolic acid & -9.72 & $75.31 \mathrm{nM}$ & 1 & ARG 819 \\
\hline Withaferin A & -11.69 & $2.69 \mathrm{nM}$ & 3 & VAL 753, ASP 833, LEU 771 \\
\hline Hecogenin & -10.50 & $20.16 n M$ & 3 & CYS 721, ASP 833, ASP 778 \\
\hline $\begin{array}{l}\text { Dovitinib } \\
\text { (Standard drug }\end{array}$ & 8.77 & $373.68 \mathrm{nM}$ & 1 & LEU 771 \\
\hline $\begin{array}{l}\text { Gefitinib } \\
\text { (Standard drug) }\end{array}$ & -6.89 & 8.83 & 2 & CYS 721, LEU 771 \\
\hline
\end{tabular}

6 phytochemicals for VEGFR-2 shown in Table 3 and Fig. 3 with-8.84Kcal $/ \mathrm{mol}$ and $-8.70 \mathrm{Kcal} / \mathrm{mol}$ binding energies for Dovitinib and Gefitinib respectively and amino acids GLU917 for Dovitinib and ASP1046 and CYS919 for Geftinib. 
Table 3 Interaction of phytochemicals with target protein VEGFR-2

\begin{tabular}{|lllll|}
\hline Phytochemicals & $\begin{array}{l}\text { Binding Energy } \\
\text { (Kcal/mol) }\end{array}$ & $\begin{array}{l}\text { Inhibition } \\
\text { constant (nM) }\end{array}$ & $\begin{array}{l}\text { Number of } \\
\text { Hydrogen bond }\end{array}$ & $\begin{array}{l}\text { Amino Acids involved in } \\
\text { hydrogen bonding }\end{array}$ \\
\hline Oleanolic acid & -9.05 & 231.22 & 2 & ARG 1027, 1LE 1044 \\
\hline Panaxadiol & -9.51 & 106.28 & 3 & $\begin{array}{l}\text { ARG 1027, HIS 1026, ILE } \\
\text { 1044 }\end{array}$ \\
\hline Panaxatriol & -9.13 & 202.47 & 3 & ARG 1027, HIS 1026, 1LE \\
\hline Ursolic acid & -9.11 & 210.11 & 3 & ASP 814, ARG 1027, ILE 1044 \\
\hline Withaferin A & -9.53 & 103.00 & 2 & GLU 885, ILE 1025 \\
\hline $\begin{array}{l}\text { Hecogenin } \\
\text { Dovitinib }\end{array}$ & -9.82 & 314.06 & 2 & ARG 1027, GLU 818 \\
\hline $\begin{array}{l}\text { (Standard drug) } \\
\text { Gefitinib }\end{array}$ & -8.84 & 331.58 & 1 & GLU 917 \\
\hline (Standard drug) & -8.70 & 422.57 & 2 & ASP 1046, CYS 919 \\
\hline
\end{tabular}

10 phytochemicals for VEGFR-3 as seen in Table 4 and Fig. 4 with binding energy of $-6.07 \mathrm{Kcal} / \mathrm{mol}$ and $-5.94 \mathrm{Kcal} / \mathrm{mol}$ for dovitinib and Geftinib respectively, having amino acid SER455, GLN457, LEU454 for Dovitinib and ASN515, TYR448 GLU391 for Geftinib.

Table 4 Binding Parameters between ligands and target protein VEGFR-3

\begin{tabular}{|c|c|c|c|c|}
\hline Phytochemicals & $\begin{array}{l}\text { Binding Energy } \\
\text { (Kcal/mol) }\end{array}$ & $\begin{array}{l}\text { Inhibition } \\
\text { constant }(\mu \mathrm{M})\end{array}$ & $\begin{array}{l}\text { Number of } \\
\text { Hydrogen bond }\end{array}$ & $\begin{array}{l}\text { Amino Acids involved in } \\
\text { hydrogen bonding }\end{array}$ \\
\hline Bassic acid & -6.14 & 31.80 & 2 & GLU 344, ASN 515 \\
\hline Nectandrin B & -6.08 & 34.69 & 3 & GLY 513, ASN 515, THR 394 \\
\hline Nimbolide & -6.58 & 15.08 & 1 & LEU 454 \\
\hline Oleanolic acid & -7.59 & 2.75 & 3 & SER 537, SER 455, LEU 454 \\
\hline Panaxadiol & -7.11 & 6.10 & 1 & LEU 454 \\
\hline Panaxatriol & -6.79 & 10.49 & 1 & ASN 515 \\
\hline Tetrandine & -6.44 & 19.13 & & \\
\hline Ursolic acid & -7.42 & 3.65 & 2 & LEU 452, GLY 513 \\
\hline Withaferin A & -7.27 & 4.72 & 3 & LEU 452, VAL 418, THR 394 \\
\hline Hecogenin & -7.45 & 3.44 & 1 & LEU 452 \\
\hline $\begin{array}{l}\text { Dovitinib } \\
\text { (Standard drug) }\end{array}$ & -6.07 & 35.59 & 3 & SER 455, GLN 457, LEU 454 \\
\hline $\begin{array}{l}\text { Gefitinib } \\
\text { (Standard drug) }\end{array}$ & -5.94 & 44.14 & 3 & ASN 515, TYR 448, GLU 391 \\
\hline
\end{tabular}


Lastly, 19 phytochemicals have binding energy comparable to standard drug for FGFR-2 (Table 5, Fig. 5),dovitinib has an energy of $-6.72 \mathrm{Kcal} / \mathrm{mol}$ with amino acid involved in hydrogen bond as ASN571, whilegeftinib has binding energy as and $-7.84 \mathrm{Kcal} / \mathrm{mol}$ and amino acid ALA567. From these results, we selected 13 phytochemicals with lowest binding energy comparable to standard drugs found in at least three of the target proteins, these where used for furtherinsilico studies.

Table 5. Interaction of phytochemicals with target protein FGFR-2

\begin{tabular}{|c|c|c|c|c|}
\hline Phytochemicals & $\begin{array}{l}\text { Binding Energy } \\
\text { (Kcal/mol) }\end{array}$ & $\begin{array}{l}\text { Inhibition } \\
\text { constant }(\mu \mathrm{M})\end{array}$ & $\begin{array}{l}\text { Number of } \\
\text { Hydrogen bond }\end{array}$ & $\begin{array}{l}\text { Amino Acids involved in } \\
\text { hydrogen bonding }\end{array}$ \\
\hline Andrographolide & -7.42 & 3.62 & 1 & ALA 567 \\
\hline Bassic acid & -7.64 & 2.51 & 4 & $\begin{array}{l}\text { GLU 574, GLU 489, ASP 644, } \\
\text { LYS } 517\end{array}$ \\
\hline Chrysin & -6.82 & 10.06 & 2 & ALA 567, LEU 487 \\
\hline Curdione & -7.27 & 4.69 & 1 & LYS 517 \\
\hline Emodin & -7.37 & 3.94 & 3 & GLU 565, ALA 567, LEU 487 \\
\hline Eriodyctiol & -6.72 & 11.96 & 3 & GLU 565, ALA 567, GLU 574 \\
\hline Isorhamnetin & -6.87 & 9.26 & 5 & $\begin{array}{l}\text { LEU 487, ALA 567, GLU 565, } \\
\text { ASP 644, GLU } 534\end{array}$ \\
\hline Nectandrin B & -7.50 & 3.20 & 3 & ASN 571, GLU 574, LYS 517 \\
\hline Nimbolide & -8.17 & 1.03 & 3 & ALA 567, ASN 631, GLU 565 \\
\hline Oleanolic acid & -8.77 & $372.58 n M$ & 1 & GLU 489 \\
\hline Panaxadiol & -9.02 & $244.6 n M$ & 1 & GLU 574 \\
\hline Panaxatriol & -8.61 & 486.38nM & 1 & GLU 574 \\
\hline Salvicine & -7.86 & 1.73 & 2 & GLU 574, ASN 571 \\
\hline Tetrandine & -7.69 & 2.32 & 2 & GLU 604, TYR 606 \\
\hline Theaflavin & -6.90 & 8.71 & 5 & $\begin{array}{l}\text { ASP 644, GLU 534, ALA 567, } \\
\text { ASN 571, GLU } 489\end{array}$ \\
\hline Tylophorine & -7.61 & 2.66 & 1 & LYS 517 \\
\hline Ursolic acid & -8.61 & $490.22 \mathrm{nM}$ & 3 & ASP 644, LYS 517, GLU 574 \\
\hline Withaferin A & -8.63 & 469.67nM & 3 & GLU 565, ALA 567, LYS 517 \\
\hline Hecogenin & -8.87 & $314.06 \mathrm{nM}$ & 1 & ALA 567 \\
\hline $\begin{array}{l}\text { Dovitinib } \\
\text { (Standard drug) }\end{array}$ & -6.72 & 11.80 & 1 & ASN 571 \\
\hline $\begin{array}{l}\text { Gefitinib } \\
\text { (Standard drug) }\end{array}$ & -7.84 & 1.80 & 1 & ALA 567 \\
\hline
\end{tabular}

Pharmacokinetic and Drug-likeness Screening of Phytochemicals 
Drug properties of the 13 selected phytochemicals were screened by Lipinski rule of five and ADME, which was followed by determining the bioavailability radar and bioactive score of the ligands. The Lipinski's rule of five checked parameters like molecular weight, hydrogen donor, hydrogen acceptor, lipophilicity, and molar refractivity $[17,18]$.Andrograholide, Bassic acid, Curdione, Nectandrin B, Nimbolide, salvicine, Withaferin A and Hecogenin satisfied all the five criteria of Lipinski, Tetrandine did not pass the criteria while the others have deviation in at most one of the criteria which is still acceptable (Table 6).

Table 6 Analysis of phytocompounds by Lipinski's Rule of 5

\begin{tabular}{|c|c|c|c|c|c|}
\hline Phytochemicals & Mass & $\begin{array}{l}\text { Hydrogen bond } \\
\text { donor }\end{array}$ & $\begin{array}{l}\text { Hydrogen bond } \\
\text { acceptor }\end{array}$ & LOGP & $\begin{array}{l}\text { Molar } \\
\text { Refractivity }\end{array}$ \\
\hline Andrographolide & 350 & 3 & 5 & 1.96 & 93.5 \\
\hline Bassic acid & 486 & 4 & 5 & 4.305 & 135.46 \\
\hline Curdione & 236 & 0 & 2 & 3.55 & 69.73 \\
\hline Nectandrin B & 344 & 2 & 5 & 4.19 & 94.21 \\
\hline Nimbolide & 466 & 0 & 7 & 3.74 & 119.39 \\
\hline Oleanolic acid & 456 & 2 & 3 & 7.233 & 132.68 \\
\hline Panaxadiol & 460 & 2 & 3 & 6.74 & 133.81 \\
\hline Panaxatriol & 476 & 3 & 4 & 5.71 & 135.20 \\
\hline Salvicine & 330 & 2 & 4 & 2.86 & 93.96 \\
\hline Tetrandine & 622 & 0 & 8 & 7.16 & 177.68 \\
\hline Ursolic acid & 456 & 2 & 3 & 7.09 & 132.61 \\
\hline Withaferin A & 470 & 2 & 6 & 3.35 & 124.46 \\
\hline Hecogenin & 430 & 1 & 4 & 4.92 & 118.11 \\
\hline $\begin{array}{l}\text { Dovitinib (Standard } \\
\text { drug) }\end{array}$ & 392 & 4 & 6 & 2.23 & 111.83 \\
\hline $\begin{array}{l}\text { Gefitinib (Standard } \\
\text { drug) }\end{array}$ & 446.5 & 1 & 7 & 4.28 & 118.15 \\
\hline
\end{tabular}

The phytochemicals were screen for ADME properties calculated from Swiss ADME a free web tool which predicts and evaluates pharmacokinetics and drug-likeness of molecules and built on several models [19]. In silico pharmacokinetics of the ligands as showed in Table 7 reveals that the drug-likeness and pharmacokinetics of some of the phytochemicals are comparable to the standard drugs. The Estimated solubility (ESOL) showed the phytochemicals curdione, andrographolide and salvicine to be more soluble than the standard drugs Dovitinib and Gefitinib with lipophilicity comparable to Dovitinib but less than Gefitinib. Lipophilicity is expressed as iLogP affects the absorption of drug, the lower the iLOGP value the higher the absorption and vice versa. Gastroinstinal absorption (GIA) and blood brain barrier (BBB) permeation are predicted by BOILED model which utilizes the polarity and lipophility of compounds [20]. GIA was high for all the ligands except oleanolic acid and ursolicacid.In line with this, the bioavailabilty score of all the ligands falls in the normal range except that of ursolic and oleanolic acids. Major therapeutic agents are substrates to p-glycoprotein, which in most cases have the potential to reduce 
absorption, permeability, oral bioavailability and retention time of drugs [21, 22].P-glycoproteins are overly expressed in cancer cells, a major barrier in cancer treatment that causes drug efflux and making chemotherapy quite ineffective [22, 23]. Hence ligands that are non-substrate of p-gp are most preferable for cancer treatment.

Table 7. In silico Pharmacokinetics of ligands using Swiss ADME

\begin{tabular}{|c|c|c|c|c|c|c|c|c|}
\hline Phytochemicals & $\begin{array}{l}\text { ESOL } \\
\text { (Log } \\
\text { S) }\end{array}$ & GIA & $\begin{array}{l}\text { BBB } \\
\text { Permeant }\end{array}$ & $\begin{array}{l}\text { P-gp } \\
\text { Substrate }\end{array}$ & $\begin{array}{l}\text { CYP3A4 } \\
\text { Inhibitor }\end{array}$ & $\begin{array}{l}\text { CYP1A2 } \\
\text { Inhibitor }\end{array}$ & (iLOGP) & $\begin{array}{l}\text { Bioavailabilty } \\
\text { Score }\end{array}$ \\
\hline Andrographolide & $\begin{array}{l}-3.18 \\
(S)\end{array}$ & High & No & Yes & No & No & 2.45 & 0.55 \\
\hline Bassic acid & $\begin{array}{l}-5.91 \\
\text { (MS) }\end{array}$ & High & No & Yes & No & No & 3.32 & 0.56 \\
\hline Curdione & $\begin{array}{l}-2.91 \\
(S)\end{array}$ & High & Yes & No & No & No & 2.80 & 0.55 \\
\hline Nectandrin B & $\begin{array}{l}-4.42 \\
\text { (MS) }\end{array}$ & High & Yes & Yes & Yes & No & 2.75 & 0.55 \\
\hline Nimbolide & $\begin{array}{l}-3.94 \\
(S)\end{array}$ & High & No & Yes & No & No & 3.51 & 0.55 \\
\hline Oleanolic acid & $\begin{array}{l}-7.32 \\
(\mathrm{PS})\end{array}$ & Low & No & No & No & No & 3.92 & 0.85 \\
\hline Panaxadiol & $\begin{array}{l}-6.96 \\
(\mathrm{PS})\end{array}$ & High & No & No & No & No & 4.61 & 0.55 \\
\hline Panaxatriol & $\begin{array}{l}-6.22 \\
(P S)\end{array}$ & High & No & Yes & No & No & 4.24 & 0.55 \\
\hline Salvicine & $\begin{array}{l}-3.58 \\
(S)\end{array}$ & High & Yes & No & No & No & 2.93 & 0.55 \\
\hline Ursolic acid & $\begin{array}{l}-7.23 \\
(\mathrm{PS})\end{array}$ & Low & No & No & No & No & 4.01 & 0.85 \\
\hline Withaferin A & $\begin{array}{l}-4.97 \\
\text { (MS) }\end{array}$ & High & No & Yes & No & No & 3.39 & 0.55 \\
\hline Hecogenin & $\begin{array}{l}-5.55 \\
\text { (MS) }\end{array}$ & High & Yes & Yes & No & No & 4.02 & 0.55 \\
\hline $\begin{array}{l}\text { Dovitinib } \\
\text { (Standard drug) }\end{array}$ & $\begin{array}{l}-3.66 \\
(S)\end{array}$ & High & No & Yes & No & Yes & 2.26 & 0.55 \\
\hline $\begin{array}{l}\text { Gefitinib } \\
\text { (Standard drug) }\end{array}$ & $\begin{array}{l}-5.05 \\
\text { (MS) }\end{array}$ & High & Yes & No & Yes & No & 4.04 & 0.55 \\
\hline
\end{tabular}

As shown in Table 7, Most of the phytochemicals are non-inhibitors of CYP3A4 and CYP1A2, members of drug metabolizing enzymes cytochrome P450, an enzyme that possesses important role in drug metabolism. The interaction of cytochrome 450 isoenzymes with drug could either result in either rapid metabolism when the drug is a substrate of any CYP causing induction or accumulation of the drug when the drug is an inhibitor that causes inhibition, which in both cases are undesirable [24]. Therefore in silico analysis in predicting the interaction of compounds or drugs with CYP isoenzymes is important in drug development process. 


\section{Bioavailability Radar}

Bioavailability radar provides a rapid assessment at the drug likeness of a compound. As seen in Figure 6, the pink area shows the optimal range of each parameter, when considering the parameters of a phytocompound the radar plot of the compound has to fall in the pink area in order to be considered drug-like, hence, the ligandsare either predicted to be orally bioavailable or not orally bioavailable via the radar plot. Flexibility (FLEX) and polarity (polar) are two essential properties that determine the bioavailabilty of compounds. Flexibility is determined by rotatable bonds, compounds with rotatable bonds $>10$ are predicted to have low oral bioavailability while polarity as determined bytopological polar surface implies that compound with TPSA $>20 \AA^{2}<130 \AA^{2}$ have high oral bioavailability [24]. Seven of the phytochemicals (Andrographolide, curdione, Nectandrin B, Nimbolide, Salvicine, Withaferin A and Hecogenic) under study are noted to satisfy the radar plot criteria, hence can be suggested to be orally bioavailable.

\section{Bioactivity score}

Bioactivity score is used to calculate the drugability properties of ligands such as GPCR, ICM, KI, NRL, PI and El. Molinspiration online server was used to predict the scores of the ligands. Scores greater than 0.00 denote high activity, scores ranging from -0.5 to -0.00 shows moderate activity while scores lower than -0.5 implies inactivity [25]. The phytochemicals under study showed a good score of high to moderate activity except for Hecogenic that showed inactivity in $\mathrm{KI}$ with a score of -0.57 as shown in Table 8. For GPCR and NRL, Andrographolide showed the highest score of 0.32 and 0.94 respectively, salivicine showed the highest score of 0.50 for ICM, Withaferin A had the highest score of $0.94 \mathrm{for} E \mathrm{El}$, while Andrographolide and Salivicine both showed high score of 0.26 for PI. Comparing this to the standard drugs Dovitinib has good scores for all the properties while Gefitinib showed inactivity in some of the properties as seen in Table 8. Good bioactivity scores revealed the potentials of these bioactives as potent therapeutic agents, the higher the scores the better the activity.

\section{Table 8. Bioactivity Score of Compounds using Molinspiration}




\begin{tabular}{|lllllll|}
\hline Compound & GPCR & ICM & KI & NRL & PI & El \\
\hline Andrographolide & 0.32 & 0.17 & -0.01 & 0.94 & 0.26 & 0.81 \\
\hline Bassic acid & 0.23 & -0.28 & -0.35 & 0.79 & 0.16 & 0.66 \\
\hline Curdione & -0.26 & -0.01 & -1.04 & -0.05 & -0.040 & -0.33 \\
\hline Nectandrin B & 0.08 & -0.16 & -0.16 & 0.20 & -0.14 & 0.10 \\
\hline Nimbolide & 0.22 & 0.22 & -0.36 & 0.32 & 0.04 & 0.36 \\
\hline Oleanolic acid & 0.26 & -0.06 & -0.40 & 0.77 & 0.15 & 0.65 \\
\hline Panaxadiol & 0.16 & 0.15 & -0.26 & 0.54 & 0.19 & 0.66 \\
\hline Panaxatriol & 0.19 & 0.16 & -0.27 & 0.55 & 0.19 & 0.73 \\
\hline Salvicine & 0.10 & 0.50 & -0.06 & 0.30 & 0.26 & 0.61 \\
\hline Ursolic acid & 0.28 & -0.03 & -0.50 & 0.89 & 0.23 & 0.69 \\
\hline Withaferin A & 0.07 & 0.14 & -0.49 & 0.76 & 0.15 & 0.94 \\
\hline Hecogenin & 0.05 & 0.04 & -0.57 & 0.47 & 0.08 & 0.61 \\
\hline Dovitinib (Standard drug) & 0.23 & 0.10 & 0.84 & -0.01 & -0.06 & 0.27 \\
\hline Gefitinib (Standard drug) & -0.18 & -0.54 & -0.07 & -0.62 & -0.67 & -0.26 \\
\hline
\end{tabular}

\section{Conclusion}

In silico study was carried out to explore the potentials of various phytochemicals to inhibit cancer growth and progression through modulation of growth factor receptors. Based on our analysis, seven phytochemicals (Andrographolide, Curdione, Nectandrin B, Nimbolide, Salvicine, Withaferin A and Hecogenic) possessed druglikeness and pharmacokinetics activities that are very comparable to the standard drugs (Dovitinib and Geftinib). This reveals that bioactive compounds have ability to bind with GFRs causing inhibition of growth factors which in turn hinders cancer cell proliferation. Further investigation is needed to establish the pharmacodynamics and kinetic properties of these phytochemicals, also mechanism of action of these phytochemicals as nanoparticle carrier of anticancer drug for effective cancer treatment can be found.

\section{Declarations}

\section{Acknowledgement}

\section{Funding}

Authors are thankful to B.S. Abdur Rahman Institute of Science \& Technology, Chennai for providing research facilities in school of life sciences. The authors also gratefully acknowledge the Ministry of Science and Technology, Department of Science and Technology (DST/SATYAM/COVID-19/2020/213 (G) and ASEAN University network (AUN)/Southeast Asia Engineering Education Development Network (SEED)/Japan International Cooperation Agency (JICA) SPRAC (SN042/MI.KU/2020).

\section{Conflicts of interest/Competing interests}


The authors declare that there is no conflict of interest

\section{Availability of data and material}

Data will be available on request

\section{Code availability}

Not Applicable

\section{Ethics approval}

Not Applicable

\section{Consent to participate}

Not Applicable

\section{Consent for publication}

All authors read and approved the manuscript for publication

\section{Authors' contributions}

SH conceived and designed research. ELM conducted experiments. All authors wrote the manuscript. All authors read and approved the manuscript.

\section{References}

1. Thun, M. J., DeLancey, J. O., Center, M. M., Jemal, A., \& Ward, E. M. (2010). The global burden of cancer: priorities for prevention. Carcinogenesis, 31(1), 100-110. https://doi.org/10.1093/carcin/bgp263

2. Choudhari, A. S., Mandave, P. C., Deshpande, M., Ranjekar, P., \& Prakash, O. (2020). Phytochemicals in Cancer Treatment: From Preclinical Studies to Clinical Practice. Frontiers in pharmacology, 10, 1614. https://doi.org/10.3389/fphar.2019.01614

3. Bray, F., Ferlay, J., Soerjomataram, I., Siegel, R. L., Torre, L. A., \& Jemal, A. (2018). Global cancer statistics 2018 : GLOBOCAN estimates of incidence and mortality worldwide for 36 cancers in 185 countries. CA: a cancer journal for clinicians, 68(6), 394-424. https://doi.org/10.3322/caac.21492

4. Abinaya, M., Priya, S., Karunya, J. R., Ranjani, S., \& Hemalatha, S. (2021).). (Screening the Efficacy of Compounds from Ghee to Control Cancer: An In silicoApproach.Biointerface research in applied chemistry, 11(6),14115-14126. https://doi.org/10.33263/BRIAC116.1411514126

5. Lutfiya, A. S., Priya, S., Manzoor, M. A. P., \& Hemalatha, S. (2019). Molecular docking and interactions between vascular endothelial growth factor (VEGF) receptors and phytochemicals: An in-silicostudy. Biocatalysis and Agricultural Biotechnology, 22, 101424. https://doi.org/10.1016/j.bcab.2019.101424

6. Tiash, S., \& Chowdhury, E. H. (2015). Growth factor receptors: promising drug targets in cancer.Journal of Cancer Metastasis and Treatment,1,190-200.http://dx.doi.org/10.4103/2394-4722.163151

7. Ornitz, D. M., \& Itoh, N. (2015). The Fibroblast Growth Factor signaling pathway. Wiley interdisciplinary reviews.Developmental biology, 4(3), 215-266. https://doi.org/10.1002/wdev.176 
8. Bennasroune, A., Gardin, A., Aunis, D., Crémel, G., \& Hubert, P. (2004). Tyrosine kinase receptors as attractive targets of cancer therapy. Critical reviews in oncology/hematology, 50(1), 23-38.

https://doi.org/10.1016/j.critrevonc.2003.08.004

9. Sarkar, B., Ullah, M. A., Islam, S. S., Rahman, M. H., \& Araf, Y. (2021). Analysis of plant-derived phytochemicals as anti-cancer agents targeting cyclin dependent kinase-2, human topoisomerase lla and vascular endothelial growth factor receptor-2. Journal of receptor and signal transduction research, 41(3), 217-233. https://doi.org/10.1080/10799893.2020.1805628

10. Atanasov, A. G., Waltenberger, B., Pferschy-Wenzig, E. M., Linder, T., Wawrosch, C., Uhrin, P. ... Stuppner, H. (2015). Discovery and resupply of pharmacologically active plant-derived natural products: A review. Biotechnology advances, 33(8), 1582-1614. https://doi.org/10.1016/j.biotechadv.2015.08.001

11. Qawoogha, S. S., \& Shahiwala, A. (2020). Identification of potential anticancer phytochemicals against colorectal cancer by structure-based docking studies. Journal of receptor and signal transduction research, 40(1), 67-76. https://doi.org/10.1080/10799893.2020.1715431

12. Anand, P., Kunnumakkara, A. B., Sundaram, C., Harikumar, K. B., Tharakan, S. T., Lai, O. S. ... Aggarwal, B. B. (2008). Cancer is a preventable disease that requires major lifestyle changes. Pharmaceutical research, 25(9), 2097-2116. https://doi.org/10.1007/s11095-008-9661-9

13. Boeing, H., Bechthold, A., Bub, A., Ellinger, S., Haller, D., Kroke, A. ... Watzl, B. (2012). Critical review: vegetables and fruit in the prevention of chronic diseases. European journal of nutrition, 51(6), 637-663. https://doi.org/10.1007/s00394-012-0380-y

14. Saklani, A., \& Kutty, S. K. (2008). Plant-derived compounds in clinical trials. Drug discovery today, 13(3-4), 161-171. https://doi.org/10.1016/j.drudis.2007.10.010

15. Tan, G., Gyllenhaal, C., \& Soejarto, D. D. (2006). Biodiversity as a source of anticancer drugs. Current drug targets, 7(3), 265-277. https://doi.org/10.2174/138945006776054942

16. Fischbach, M. A., \& Walsh, C. T. (2006). Directing biosynthesis. Science, 314(5799), 603-605. https://doi.org/10.1126/science.1132692

17. Lipinski, C. A. (2004). Lead- and drug-like compounds: the rule-of-five revolution. Drug discovery today. Technologies, 1(4), 337-341. https://doi.org/10.1016/j.ddtec.2004.11.007

18. Jayaram, B., Singh, T., Mukherjee, G., Mathur, A., Shekhar, S., \& Shekhar, V. (2012). Sanjeevini: a freely accessible web-server for target directed lead molecule discovery. BMC bioinformatics, 13 Suppl, 17(Suppl 17), S7.https://doi.org/10.1186/1471-2105-13-S17-S7

19. Daina, A., Michielin, O., \& Zoete, V. (2017). SwissADME: a free web tool to evaluate pharmacokinetics, druglikeness and medicinal chemistry friendliness of small molecules. Scientific Report, 7, 42717. https://doi.org/10.1038/srep42717

20. Daina, A., \& Zoete, V. (2016). A BOILED-egg to predict gastrointestinal absorption and brain penetration of small molecules.ChemMedChem, 11 (11), 1117-1121. https://doi.org/10.1002/cmdc.201600182

21. Lin, J. H., \& Yamazaki, M. (2003). Role of P-glycoprotein in pharmacokinetics: clinical implications. Clinical pharmacokinetics, 42(1), 59-98. https://doi.org/10.2165/00003088-200342010-00003

22. Amin, M. L. (2013). P-glycoprotein Inhibition for Optimal Drug Delivery. Drug target insights, 7, $27-34$. https://doi.org/10.4137/DTI.S12519

23. Bansal, T., Jaggi, M., Khar, R. K., \& Talegaonkar, S. (2009). Emerging significance of flavonoids as Pglycoprotein inhibitors in cancer chemotherapy. Journal of pharmacy \& pharmaceutical sciences: a publication 
of the Canadian Society for Pharmaceutical Sciences, Societecanadienne des sciences pharmaceutiques, 12(1), 46-78. https://doi.org/10.18433/j3rc77

24. Ji, D., Xu, M., Udenigwe, C. C., \& Agyei, D. (2020). Physicochemical characterisation, molecular docking, and drug-likeness evaluation of hypotensive peptides encrypted in flaxseed proteome. Current Research in Food Science, 3, 41-50. https://doi.org/10.1016/j.crfs.2020.03.001

25. Khan, T., Dixit, S., Ahmad, R., Raza, S., Azad, I., Joshi, S., \& Khan, A. R. (2017). Molecular docking, PASS analysis, bioactivity score prediction, synthesis, characterization and biological activity evaluation of a functionalized 2butanone thiosemicarbazone ligand and its complexes. Journal of chemical biology, 10(3), 91-104. https://doi.org/10.1007/s12154-017-0167-y

\section{Figures}
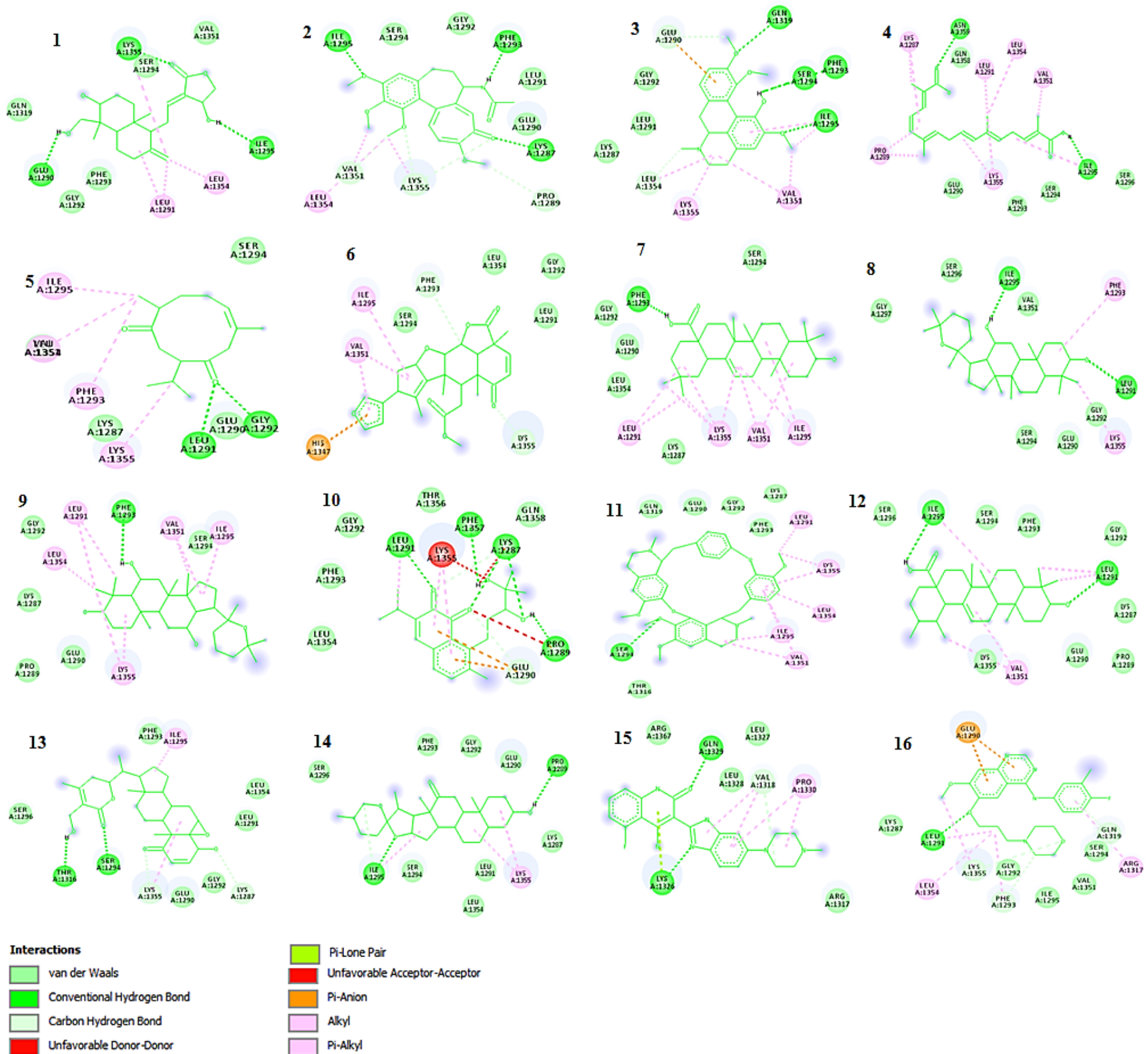

Pi-tone Pair

Unfavorable Acceptor-Acceptor

Pi-Arion

Alkyl

Pi-Alkyl 
Figure 1

2D Interaction of phytocompounds with HER-2.(1)Andrographolide (2)Colchicine (3) Corydine (4) Crocetin (5) Curdione (6) Nimbolide (7) Oleanolic acid(8) Panaxadiol (9) Panaxatriol (10) Salvicine (11) Tetrandrine (12) Ursolic acid (13) Withaferin A (14) Hecogenin (15) Dovitinib (16) Gefitinib
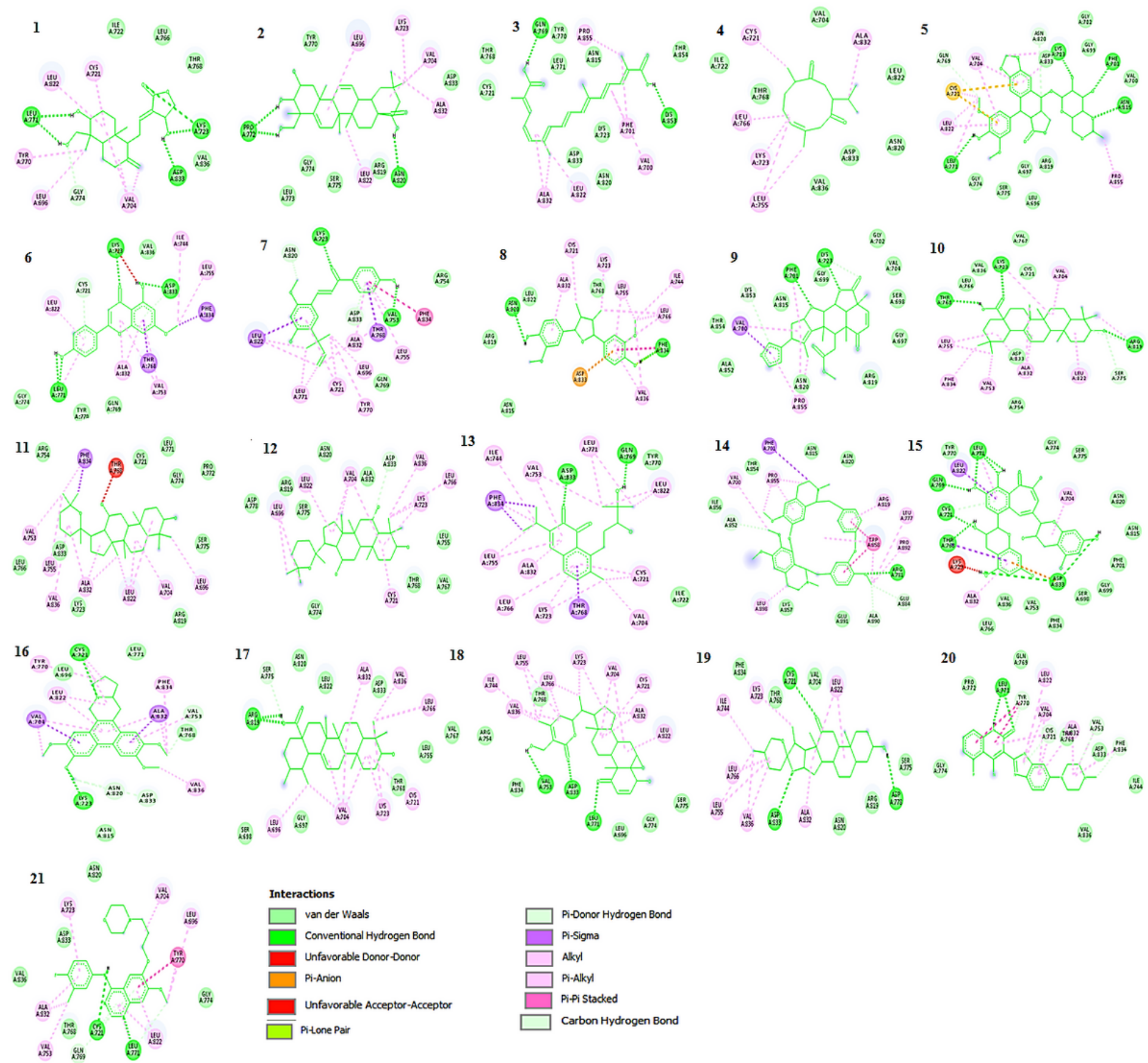

Figure 2

2D Interaction of phytocompounds with HER-3.(1)Andrographolide(2) Bassic acid(3)Crocetin(4) Curdione(5) Etoposide(6) Genkwanin(7) Licochalcone A(8) Nectandrin B(9) Nimbolide(10) Oleanolic acid(11) Panaxadiol(12) Panaxatriol(13) Salvicine(14) Tetrandrine(15) Theaflavin(16) Tylophorine(17) Ursolic acid(18) Withaferin A(19) Hecogenin(20) Dovitinib(21) Gefitinib 

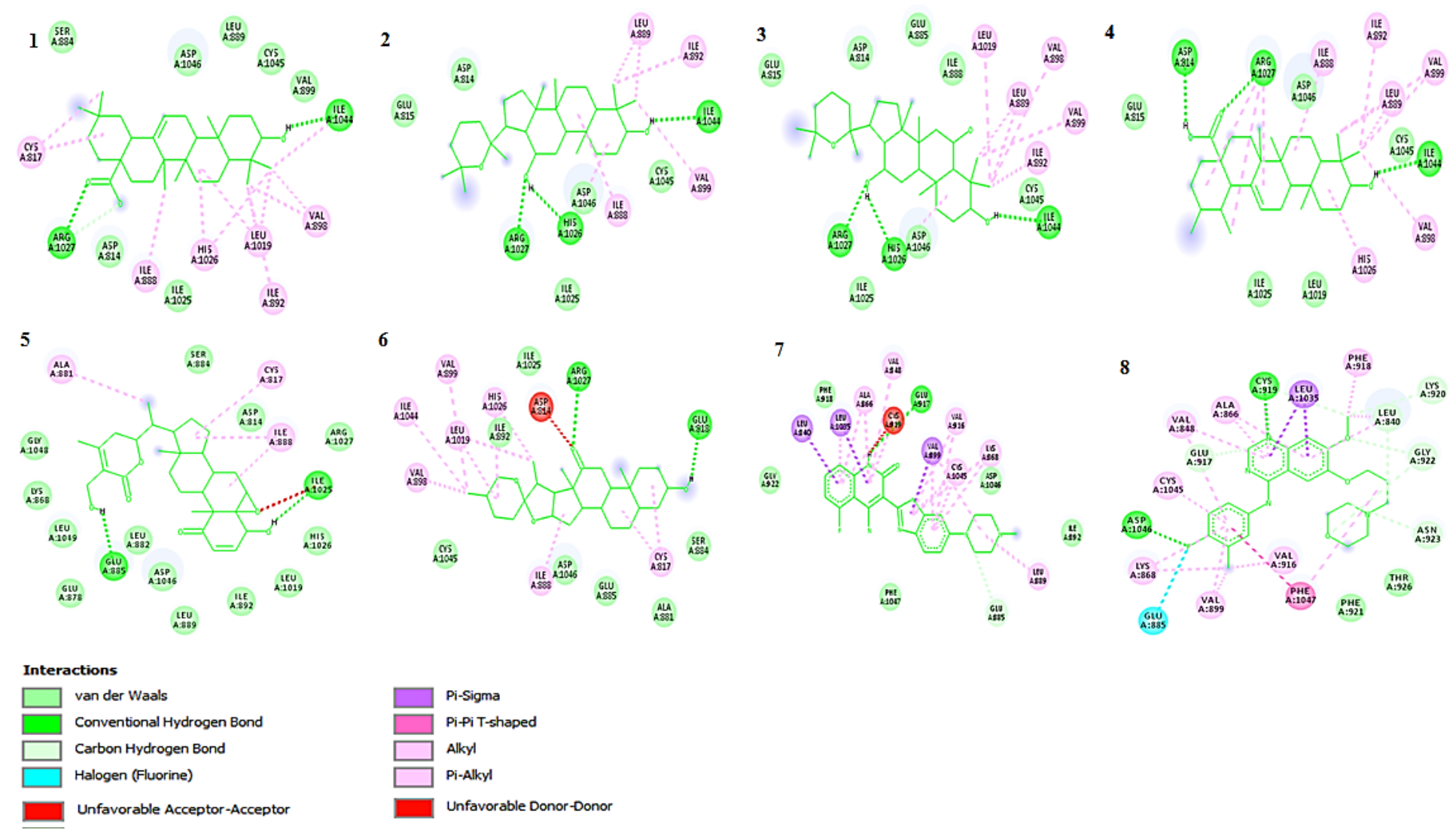

Figure 3

2D Interaction of phytocompounds with VEGFR-2.(1)Oleanolic acid (2) Panaxadiol (3) Panaxatriol (4) Ursolic acid (5) Withaferin A (6) Hecogenin(7) Dovitinib(8) Gefitinib 

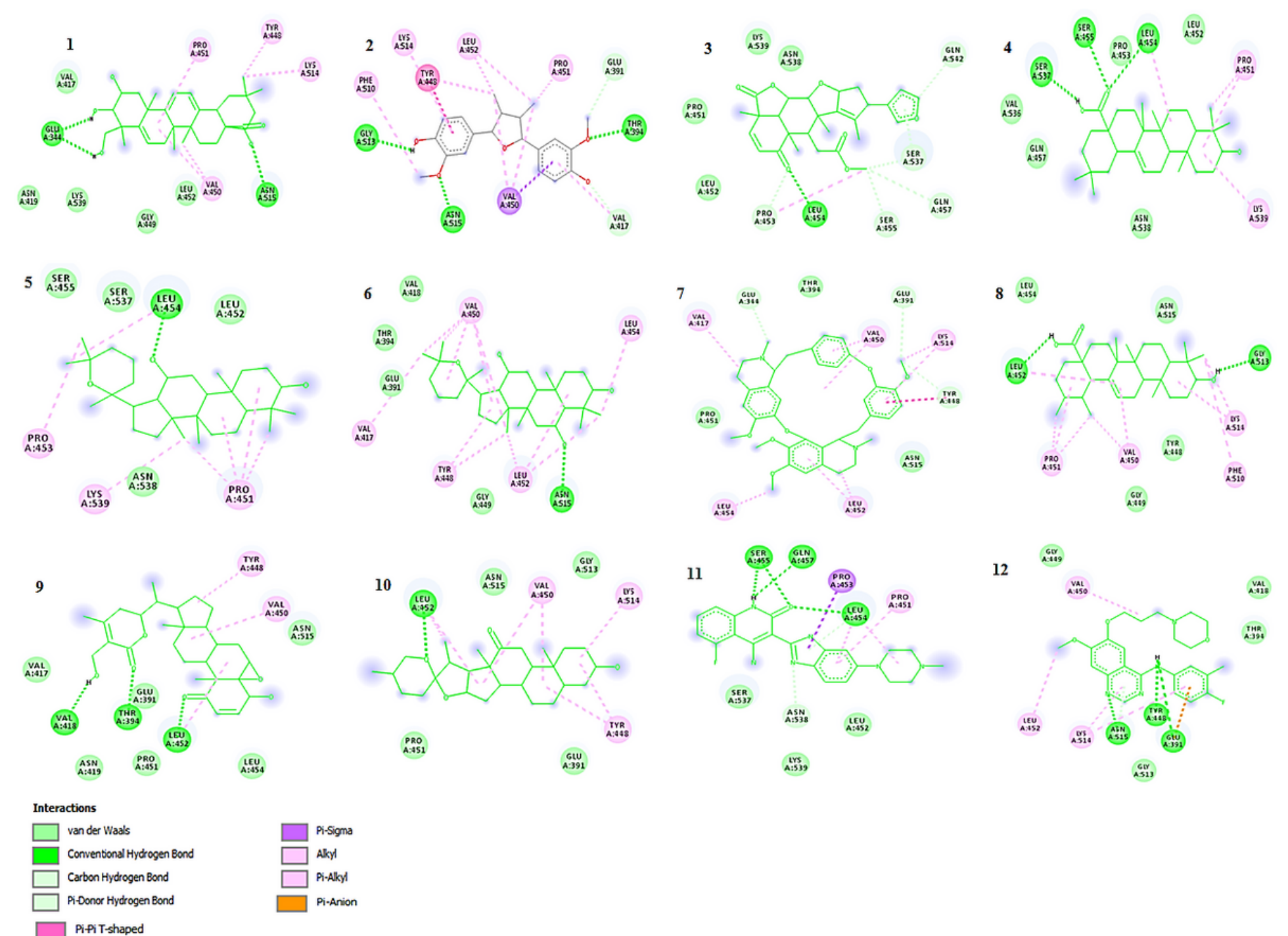

\section{Figure 4}

2D Interaction of phytocompounds with VEGFR-3.(1)Bassic acid(2)Nectandrin B (3)Nimbolide (4) Oleanolic acid (5) Panaxadiol (6) Panaxatriol (7) Tetrandine(8) Ursolic acid (9) Withaferin A (10) Hecogenin(11) Dovitinib(12) Gefitinib 

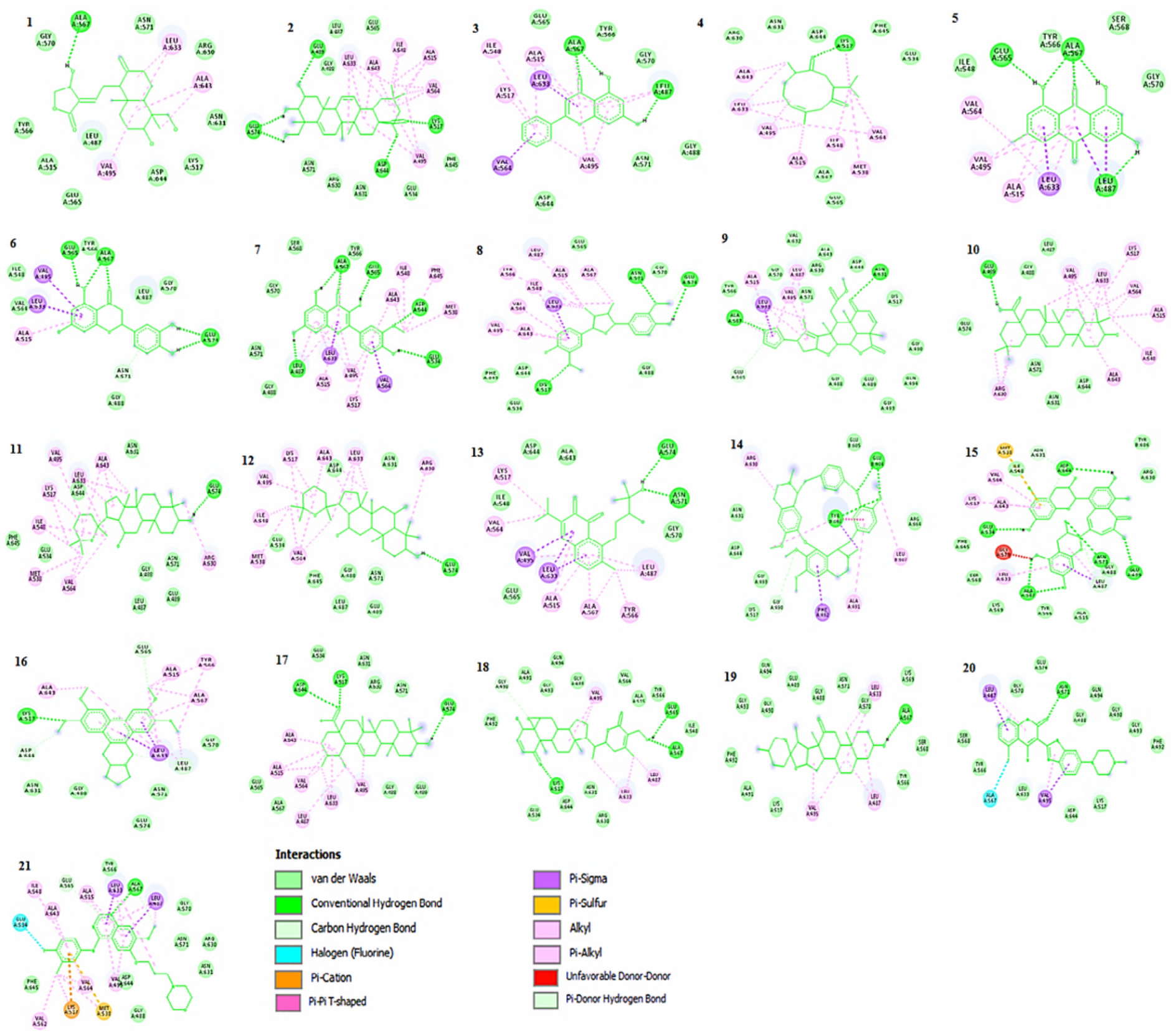

\section{Figure 5}

2D Interaction of phytocompounds with FGFR-2.(1)Andrographolide(2) Bassic acid(3) Chrysin (4) Curdione (5) Emodin(6) Eriodyctiol (7) Isorhamnetin (8) Nectandrin B (9) Nimbolide (10) Oleanolic acid (11) Panaxadiol (12) Panaxatriol (13) Salvicine (14) Tetrandrine (15) Theaflavin (16) Tylophorine (17) Ursolic acid (18) Withaferin A (19) Hecogenin (20) Dovitinib(21) Gefitinib 

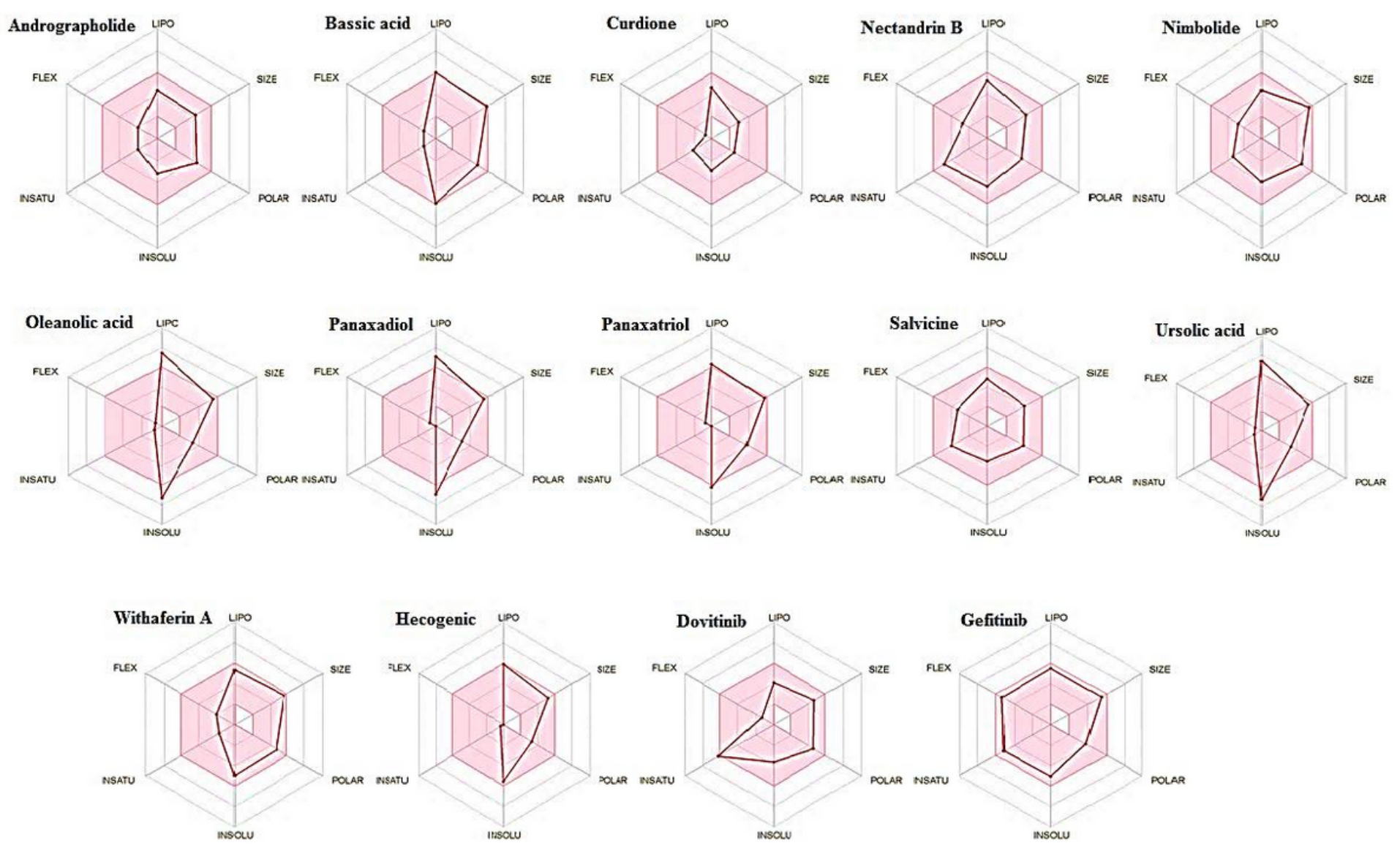

\section{Figure 6}

Radar plots of phytocompounds used for the current study. 